Article

\title{
What Role Does the Housing Market Play for the Macroeconomic Transmission Mechanism?
}

\author{
Mats Wilhelmsson \\ Division of Real Estate Economics and Finance, Royal Institute of Technology (KTH), \\ S-100 44 Stockholm, Sweden; mats.wilhelmsson@abe.kth.se
}

Received: 29 April 2020; Accepted: 26 May 2020; Published: 1 June 2020

\begin{abstract}
The main objective is to answer the question: What role does the housing market play for the transmission mechanism and (in particular) is the impact constant over time? The research question also includes analyzing the importance of the housing market for the transmission mechanism. We estimate an eight-variable structural vector autoregression (SVAR) model of the Swedish economy over the period 1993 and 2018 using quarterly data, covering both the internet bubble in 2000 and the financial crises in 2008. The results indicate that interest rates have both a direct effect on housing prices and an indirect impact through the bank lending channel. Over time, the traditional interest rate channel importance has been stable. On the other hand, the role of the bank lending channel has increased over time. Household debt has increased substantially in Sweden and elsewhere. That means that the interest rate sensitivity in society has increased. Based on the results, it is possible to evaluate and forecast potential house price effects (both direct and indirect) when the interest rate changes.
\end{abstract}

Keywords: monetary policy; transmission mechanism; bank lending; house prices; structured VAR; Granger causality

\section{Introduction}

Macroeconomics is about how fiscal and monetary policy influence how much a country produces, the overall price level, and the unemployment level (Abel et al. 2014). Fiscal policy, with government spending and taxes, means that that there is a direct impact on aggregate demand and supply. For example, gross domestic product (GDP) is increased in the event of a recession or decrease in the event of overheating in the economy. Monetary policy is more indirect than fiscal policy. Here, the central bank intends to influence the interest rate via, for example, money supply, which in turn can affect, for example, consumption and the aggregated demand. An increase in the money supply implies that interest rates fall, and the exchange rate depreciates in an open economy, which increases consumption and GDP. Monetary policy's impact on the real economy goes through the so-called transmission mechanism. Hence, the effect of a change in interest rates will not only have an impact on output and price level, but it will also affect, for example, exchange rates and asset prices. Low-interest rates tend to increase house prices and bank lending.

For more than ten years, up to 2017, house prices have increased on an annual basis in Sweden. At the same time, household debt has increased substantially. Low interest rates have fostered both high house prices and high household debt over the period. The low interest-rate environment is, among other things, a result of the ambition to increase inflation to 2 percent on an annual level (with a tolerance interval of \pm 1 percentage point). The risk with the ever-higher housing prices and higher household debt is that both financial and real economic risks have increased. Households are more sensitive to interest rate changes, and banks are more sensitive to foreclosures if interest rates rise. 
This risk has been heightened as more and more households have mortgage loans with adjustable interest rates.

The primary purpose of the paper is to analyze the relationship and the transmission mechanism channel between the housing market (house prices and housing supply), the financial market (bank lending and the stock market), and the overall economy (consumption, gross domestic product, and exchange rate). Hence, the overall research question is, what role does the housing market play for the transmission mechanism? First, we are analyzing the response of output growth and consumption, as well as housing supply and house prices, to shocks in monetary tightening, with an impulse response function. Second, we are explaining the variability of the response by monetary policy shocks and other structural shocks by a forecast error variance decomposition.

Our contribution to this analysis is that we can analyze the effects of monetary policy on housing prices and investment in housing over a relatively long period, from 1992 to 2019. The analysis also allows us to distinguish which transmission mechanism is the most prominent and whether it has changed over time when the institutional context has changed in a given country, here the case of Sweden. The empirical method we use is by no means new, but it has a more explicit focus on direct and indirect effects on asset prices and investment compared to previous literature. In contrast to other countries that have been investigated, Sweden is a relatively small open economy, which is highly dependent on global trade. This fact adds to the knowledge of the importance of the transmission mechanism in different types of economies.

The structural VAR model is used to analyze whether it is plausible to evaluate each transmission mechanism channel separately. If that can be done, we can gather more evidence on whether monetary policy has a more pronounced effect on the economic activity in today's global economy. Understanding how changes in monetary policy affect economic activity may help us foresee the effect of changes in money supply and asset prices more accurately. Moreover, by understanding how the real and financial economy works and interacts, we may be able to predict how institutional changes in the economy might affect the link between changes in money supply and asset prices, as well as residential investments.

The remainder of the paper is organized as follows. Section 2 describes the theoretical framework and a brief literature review. Here, our main hypotheses will also be presented, and Section 3 presents the methodological approach used to answer the research questions. Section 4 presents the empirical analysis and discusses the results and, finally, Section 5 concludes.

\section{Theoretical Framework}

Monetary policy aims to influence aggregate demand through the money market, where supply and demand for short-term credits meet. By changing the money supply or the interest rate, the purpose is to influence the real economy, such as employment and output, via various channels in the so-called transmission mechanisms. Mishkin (2007) presents several different transmission mechanisms. The traditional channel is the interest-rate channel, where an expansionary monetary policy leads to a fall in real interest rate, which lowers the cost of capital, which increases the investment spending within the business sector and increases housing and consumer expenditure in the household sector. Housing is particularly important as housing represents a significant part of the net wealth and plays a significant part in the banking sector as housing is used as collateral (Giuliodori 2005). The monetary transmission mechanism to consumption through the housing market will have a direct effect where an increase in interest rates will increase interest payment and lower consumption. In the Swedish context, this effect will be significant as most of the household has an adjustable interest rate mortgage.

Mishkin also presents some other channels. From a credit view, the bank lending channel and the household liquidity effect channel are directly indicating an impact on residential housing. As the name suggests, in the bank lending channel, banks play a unique role where an expansionary monetary policy increases bank deposits and bank lending (Bernanke and Blinder 1988). An increase in credit supply will cause investment and residential spending to increase. One indirect effect, 
or complimentarily effect, is the bank lending channel, where the availability of loans will affect investment in residential housing.

Another indirect effect will channel through the housing market with lower house prices, which will lower both owner-occupied wealth and collateral value of houses that will reduce consumption for credit constraint households (household liquidity effect channel). The household liquidity channel is based on the view that households desire to spend. In an expansionary monetary policy environment, the value of financial and real assets will increase and thereby lower the likelihood of financial distress, which will increase spending on consumption and spending on residential housing. The main drivers we are going to analyze are, therefore, the impact of interest rate, bank lending, and wealth on house prices and residential investments.

The efficiency of the transmission mechanism will largely depend on how efficient the Swedish housing market is. Over the years, there have been changes, both in the housing market and in the housing mortgage market, which will influence the transmission mechanism and which channel is most effective.

There are, above all, four institutional changes that will affect the efficiency of the transmission mechanism over time, which has to do with the housing market. First, it has to do with a redistribution between ownership and tenancy. If the proportion of ownership increases, the effect of monetary policy will most likely also increase. The reason for this is that the rental market in Sweden mainly has rent control, which means that the effect of a change in interest rates has a much more delayed effect on other consumption. According to data from Statistics Sweden, the share of owner-occupied apartments has increased from less than 25 percent in 1993 to more than 60 percent in 2018.

Second, the proportion of households with an adjustable housing mortgage interest rate has increased over time. This means that more households are more sensitive to changes in interest rates. Hence, it will affect other consumption much more directly. According to a report from the Sveriges Riksbank (Economic comments, no. 7, 2015), the percentage of adjustable interest rates in the housing loan portfolio has increased from less than 10 percent in the mid-1990s to about 60 percent in 2015. The proportion that has fixed interest rates on a mortgage has decreased. The ratio of fixed interest rate mortgages (5-year fixed mortgage) in the mid-1990s was more than 70 percent. Today, that proportion is down to about $30-35$ percent. From an international perspective, it can be noted that the average fixed interest term is among the shortest, with an average time of fewer than three years. Thus, it is clear that household interest rate sensitivity has increased in general, and a change in the interest rate will have a much faster impact on consumption today compared to 20-30 years ago.

Third, the gap between how much is being built and population growth has been unbalanced over the last few decades. If the population growth increases faster than construction, it will create pressure on the housing market, and housing prices will rise more. One effect this may have is that households must spend more of their disposable income on housing, which reduces other consumption and reduces GDP. Even the decline in residential construction will have a direct effect on GDP. According to statistics from Statistics Sweden, the construction of new dwellings has been halved since the beginning of the 1990s.

Finally, there have been institutional changes in the mortgage market with the introduction of different types of macroprudential tools, such as the introduction of higher loan-to-value ratios and repayment requirements. To sum up, all these institutional changes suggest that the interest rate channel and the bank lending channel is more important today compared to 20 years ago.

\section{Literature Review}

The literature linking bank lending and house prices using Granger causality type of models is extensive. Some of the most cited articles are, for example, Gerlach and Peng (2005), Goodhart and Hofman (2008), Oikarinen (2009), and Anundsen and Jansen (2013). Gerlach and Peng (2005) analyze the relationship between bank lending and housing prices in Hong Kong during the period 1980-2000. From a theoretical perspective, they argue that the relationship can go both ways. Housing prices 
affect both the demand for credit and the availability of credit. By estimating a vector error correction model with the variables bank lending, housing prices, and GDP, they find that the effect is only from housing prices to housing loans, that is, the conclusion that can be drawn is that the transmission effect and bank lending channel did not then have any effect on housing prices. The article by Goodhart and Hofman (2008) analyzed the relationship between credit, house prices, and economic activity using panel data across 17 countries over the period 1970-2006. Their results suggest that there is a bi-directional relationship between the monetary variables and house prices and that this relationship has been more substantial over time.

By using Finnish quarterly data from 1975 to 2006, Oikarinen (2009) shows that the relationship between bank lending and house prices has been bi-directional and has become stronger after the financial deregulation. Anundsen and Jansen (2013) also conclude a bi-directional relationship between housing prices and bank lending in Norway, using data over the period 1986-2008. A recent article by Öhman and Yasdanfar (2017) is analyzing the Swedish housing market over the period 2005-2013. They are estimating a VAR model with the variables bank lending, housing prices, mortgage rate, and CPI. First, they conclude that bank lending and housing prices are cointegrated. Moreover, based on the Granger causality test, the relationship is bi-directional. That is, they are finding support that there is a link between the real economy and the financial markets, that is, the financial accelerator mechanism (Bernanke and Gertler 1989).

Giuliodori (2005) analyzes the importance of the housing market for the transmission mechanism in nine European countries over the period 1979 to 1998. Methodically, they use a VAR where the variables CPI, GDP, house prices, and money interest rates are included in the model. The conclusion is that housing prices are noticeably affected by changes in monetary policy. The effect reaches its maximum at 1 to 2 years after a change in interest rates. In a second step, changes in housing prices will affect consumption via, for example, wealth effect or balance sheet effect. The result shows that the countries that have a well-developed housing and housing loan market, monetary policy have a more significant impact on consumption compared to other countries. That is to say, the transmission mechanism is more effective.

Elbourne (2008) estimated a structured VAR model for the UK economy over the period 1987 to 2003 with monthly data. To identify the structural VAR model, they are using contemporaneous restriction. They include eight variables in their model (commodity price, the Federal Fund rate, retail sales, price level, money demand and supply, exchange rate, and real house prices). Their results indicate that retail sales fall by $0.4 \%$, by a fall in interest rate by $0.1 \%$. The effect on house prices is about $0.75 \%$. Positive house price shocks increase consumption, price level, and interest rate. Moreover, their results suggest that consumption will fall by $12 \%-15 \%$ via housing prices due to a monetary policy shock. That is a significantly lower estimate than, for example, Giuliodori (2005), who estimated it to be as high as $60 \%-70 \%$.

Iacoviello and Minetti (2008) test the bank-lending and balance-sheet channel using a VAR approach in Finland, Norway, Germany, and the UK. The identification scheme they are using is a combination of short and long-run restrictions. In Finland and the United Kingdom, there is evidence for the support of a bank-lending channel. In Germany, the results support the balance-sheet channel but not the bank-lending channel, while in Norway, there is no evidence of a credit channel. Hence, they conclude that, despite the integration of the markets, the transmission mechanism varies depending on the institutional context.

Björnlund and Jacobsen (2010) also analyzed the role that the housing market and the mortgage loan market have on monetary policy's transmission mechanism. The variables they use in the structural vector autoregression (SVAR) model are foreign interest rates, real GDP, inflation, real housing prices, exchange rates, and domestic interest rates. They use quarterly data from 1983 to 2006. By analyzing the United Kingdom, Norway, and Sweden, they conclude that the effect of monetary policy is, to a large extent, affected by country-specific institutional differences. The result of 
a contractionary monetary policy shock leads to a fall in prices in the housing market. Still, the price effect is relatively small compared to the price volatility in the housing market.

Wadud et al. (2012) are analyzing the Australian housing market and its impact on the effectiveness of the monetary policy. They are using a single-country structured VAR model utilizing quarterly data from 1974 to 2008. The data they are using is GDP, CPI, house price index, material cost, and construction of new residential and federal funds rate. The identification scheme is not assuming that foreign interest rate, GDP, CPI, and government spending have any contemporary effect on housing demand and supply. Their results indicate that monetary policy does have an impact on the activity, but surprisingly not on prices.

Calza et al. (2013) find that countries with more adjustable interest rates have a more substantial monetary policy effect on residential investments and housing prices. It is also found that the transmission to consumption is stronger in countries with more flexible interest rates on home loans. Variables included in the VAR model are private consumption, residential investment, the consumer price index, the real house price, a three-month interbank interest rate, and the real effective exchange rate.

A recent article by Rahal (2016) is the unconventional monetary policy's impact on housing prices, mortgage interest rates, and housing investments investigated. By using a structured VAR model utilizing monthly data from 2007 to 2014 over seven countries and the euro area, they conclude that there is a persistent response from a policy shock on housing prices and housing investments. The results concerning Sweden suggest that the impact on housing prices peaked within 1-2 years, while for housing investment, the impact is more substantial and peak 2-4 years after the policy shock.

Recently, Yang et al. (2017) estimated a panel VAR model for the Chinese economy, where they analyzed the effect of monetary policy on consumption through the housing market and the housing wealth/liquidity channel. They used both national and regional data over the period 2006-2010. Variables included in the VAR model are consumption, income, house prices, and interest rate (or money supply). Despite the relatively short period investigated, for example, including the great financial recession, their results are interesting. On a national level, their results, from the counterfactual model, indicate that the household liquidity channel is modest. The regional results show that the housing market and household wealth play a more prominent role in regions with high house prices and, therefore, where the households are more interest-rate sensitive.

Using monthly data from 2005 to 2015, Wu and Bian (2018) estimate a SVAR model. They do not use aggregated data at a national level, but disaggregated data in so-called first-, second- and third-tier cities in China. The housing markets differ, and the hypothesis is that the effect of an active monetary policy will have a different impact depending on the city. They conclude that the effect shows many similarities but also significant differences. One difference is that the effect of a change in interest rates is much more prominent in first-tier cities such as Beijing and Shanghai. One reason for this is probably that the housing price level varies between the different cities, as Yang et al. (2017) discuss.

Furthermore, Christidou et al. (2018) analyze the effect of monetary policy on the housing market, in terms of both prices and investments. They conclude that at a national level, both housing prices and housing investments will be affected but that there is a significant regional difference. In some states, the impact of monetary policy is relatively limited, while in others, it is substantial. Their empirical conclusion is that states with a high proportion of older people, higher population density, and more substantial income disparities within the state, show more significant effects of the monetary policy compared to other states. A reasonable explanation for this is that most of the characteristics affect both the level of housing prices and the loan-to-value ratio. In an interesting and recently published article, Fisher et al. (2019), the effect of monetary policy on regional housing markets around the US is also analyzed. The results from their VAR model and impulse response functions using monthly data from 1997 to 2012 show that the effect can vary considerably between regions. The reason for this is mainly due to local institutional differences between the various housing markets and the elasticity of 
the housing supply. It further clarifies the importance of assuming that the effect is constant over time is incorrect.

\section{Methodology Approach}

The modeling approach we will use is the vector autoregressive model (VAR) presented by Sims (1980). The general form of VAR is a system of regression models, where each variable is partly the dependent variable and partly independent variables. We assume all variables to be endogenous. This assumption makes VAR models non-theoretical. Equation (1) shows a simple bivariate VAR with two variables, namely $y$ and $z$.

$$
\begin{aligned}
& y_{t}=\rho+A_{1} y_{t-1}+A_{2} z_{t-1} \\
& z_{t}=\rho+A_{1} y_{t-1}+A_{2} z_{t-1}
\end{aligned}
$$

The Granger causality can be tested by statistically testing the significance of $A_{2}$ in the first equation and $A_{1}$ in the second equation. If $A_{2}$ in the first equation is statistically significantly different from zero, $z$ is said to Granger cause $y$. If $A_{1}$ in the second equation is statistically significantly different from zero, $y$ is said to Granger cause $z$. In that case, we have a bidirectional relationship between the two variables. Here, we are going to use F-test to test for Granger causality among the included variables.

By including some restrictions, it is possible to identify the parameters and put more theoretical structure on the model. Here, we will include short-term restrictions to estimate a structured VAR model (SVAR). The SVAR model is shown in Equation (2).

$$
\begin{aligned}
& B y_{t}=\rho+A_{1} y_{t-1}+A_{2} z_{t-1} \\
& B z_{t}=\rho+A_{1} y_{t-1}+A_{2} z_{t-1}
\end{aligned}
$$

where $B$ is a matrix of restrictions. We are using zero restrictions to identify the relationship of the included variables. The $B$ matrix will be defined based on the expected impact, based on the three transmission mechanism channels discussed above, namely the traditional interest rate channel, the bank lending channel, and the liquidity channel. We intend to estimate the effect on GDP of a change in interest rates (IR), through the effects of the transmission mechanism on housing prices (HP), housing investment (HI) and bank lending (BL), as well as consumption (CON), the exchange rate (FX) and the stock market index (OMX). The order here will be GDP, CON, HI, HP, OMX, BL, FX, IR. The order of the variables is important if the stochastic error from each equation is highly correlated to each other, which we can assume. The following matrix summarizes our identification scheme. It is an inverse variation of the Cloleski decomposition identification triangular matrix.

$$
B=\left[\begin{array}{cccccccc}
1 & . & . & 0 & 0 & 0 & 0 & 0 \\
0 & 1 & 0 & . & . & . & 0 & . \\
0 & 0 & 1 & . & 0 & . & 0 & . \\
0 & 0 & 0 & 1 & . & . & 0 & . \\
0 & 0 & 0 & 0 & 1 & . & . & . \\
0 & 0 & 0 & 0 & 0 & 1 & . & . \\
0 & 0 & 0 & 1 & 0 & 1 & 1 & . \\
0 & 0 & 0 & 0 & 0 & 0 & 0 & 1
\end{array}\right]
$$

where "." denotes the coefficients to be estimated. The zeros are contemporaneous restrictions on the structural parameters. We add no further restrictions on the lagged structural parameters. Hence, it is a short-run structural VAR model. In the above system of restrictions, the third and fourth row of restriction represent the contemporaneous relations in the housing markets, namely housing prices and housing construction. The main problem with VAR and, to some extent, structured VAR is that they are non-theoretical and that it is difficult to identify the parameters. Of course, structured VAR is an attempt to solve the identification problem. Of course, if you have reached all the way, it is difficult to know. 
We expect no contemporaneous effect on GDP from shocks in the other variables expect from consumption and housing investments. For consumption, we expect effects contemporaneously only from the stock market and bank lending. Moreover, we expect housing prices to react immediately to shocks in the stock market, bank lending, and interest rate. On the other hand, we expect no contemporaneous effects on housing investments-moreover, bank lending contemporaneous effects house prices, the stock market, and interest rates. The stock market is affected by house prices, bank lending, and interest rates. Finally, the exchange rates are affected by all other variables, and the interest rate is affected by bank lending and the exchange rate.

Forni and Gambetti (2014) emphasize the importance of including all relevant variables in the VAR model (Chari et al. 2008). Forni and Gambetti (2014) are proposing a method using an extensive data set with all available macroeconomic variables and a principal component approach. In a second step, they are testing the Granger causality between the principal components included in VAR. Sufficient information is included in VAR if the null hypothesis of no Granger causality is not rejected. Hence, they conclude that "a VAR contains enough information to identify and estimate the structural shocks if, and only, if, they are not Granger caused by common factors (the 'states') driving macroeconomic variables." Here, we are Granger causality testing included variables in our (structured) VAR model without additional macroeconomic variables included in the model. There are several methods to find out the optimal lag structure in the model. Here, we will use the Aiken information criteria (AIC), Schwarz's Bayesian information criterion (SBIC), and the Hannan and Quinn information criterion (HQIC) lag-order selection statistics.

The impulse response function and the variance decomposition of the structured VAR model have been utilized to analyze the dynamic effects of the system when the model received the impulse. An impulse response is the response of any dynamic system in reaction to external shock. To calculate the impulse response function, the order of the VAR model structure is essential. Here, as mention above, the order will be determined based on the theory. The interpretation of the results from impulse responses and variance decomposition is difficult. Here, we will not focus on the individual point estimates, but rather focus on the general trends of the result.

By analyzing a shock in each variable, it is possible to estimate the effect on the dependent variable; the so-called forecast error variance decomposition. The variance of the dependent variable due to the shock can be considered as the variance of the forecast, and the question we want to answer is how much of this variance can be explained by each shock in the other variables. Hence, the variance decomposition shows the amount of information each variable contributes to the other variables in the vector autoregression. It permits one to determine how much of the variability independent variable is lagged by its variance. Moreover, it shows which of the independent variables is "stronger" in explaining the variability in the dependent variables over time.

\section{Empirical Analysis}

\subsection{Data}

We are using Sweden as a case study, and we are using quarterly data over the period 1993 to 2017. The variables included in the analysis are real bank lending (BL) to the households, real gross domestic product (GDP), and real consumption (CON) from the national accounts, real house prices (HP) on owner-occupied single-family houses and housing investments (HI) measured as the number of new dwellings, as well as the real interest rate (IR) on three-month government bonds, exchange rates (FX) of SEK to a basket of other currencies based on trade weights, and real stock market index (OMX). The sources of the data are Statistics Sweden, the Central bank, and NasdaqOMX. All series are deflated with consumer price index, as well as trend and seasonally adjusted. All first-difference series are integrated of order 1, that is, they are all stationary and can be utilized in the structural VAR model. All estimates have been made with Stata 15.1. In Figure 1, all series are exhibited. 


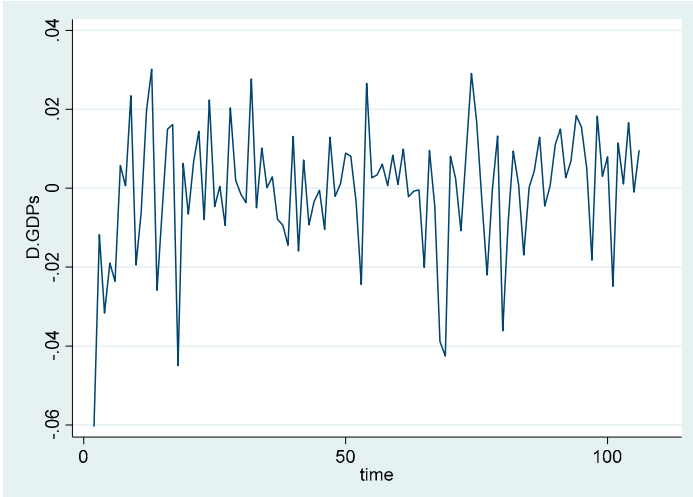

(a)

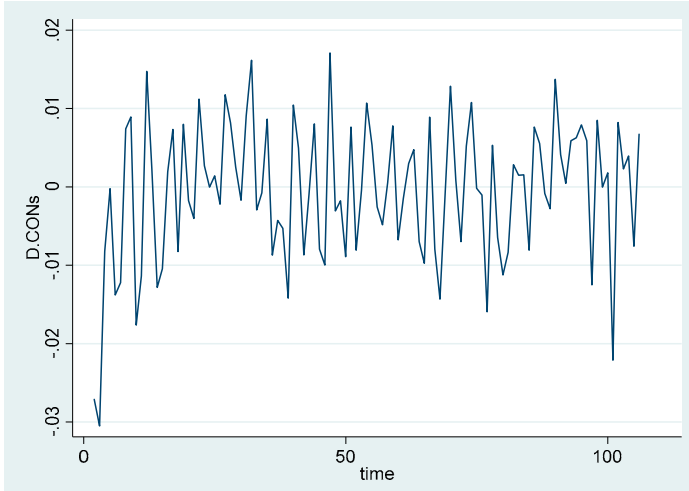

(c)

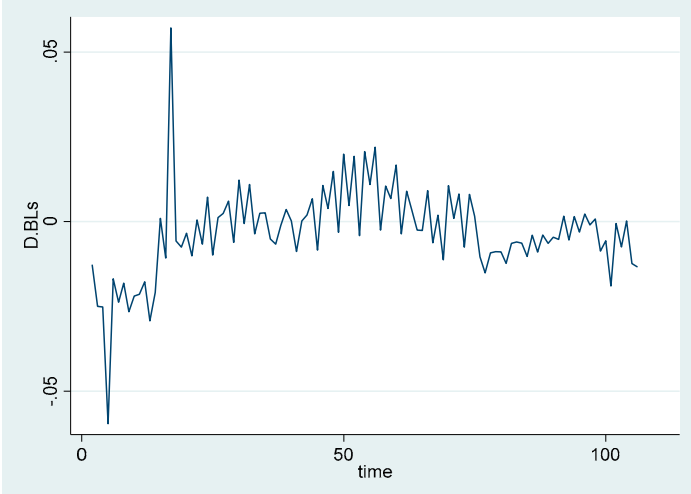

(f)

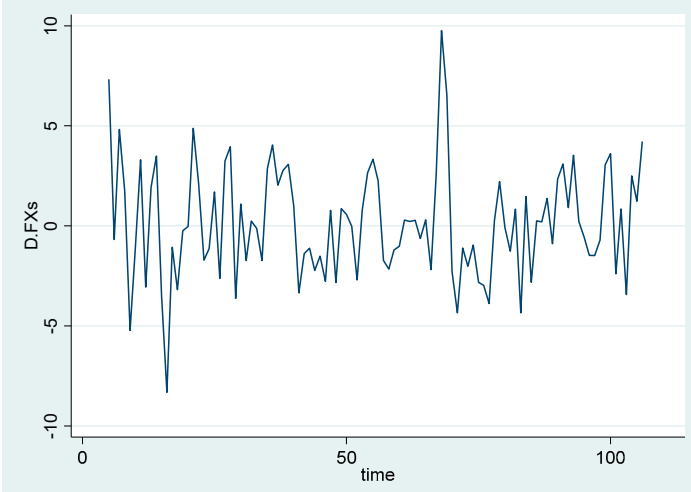

(h)

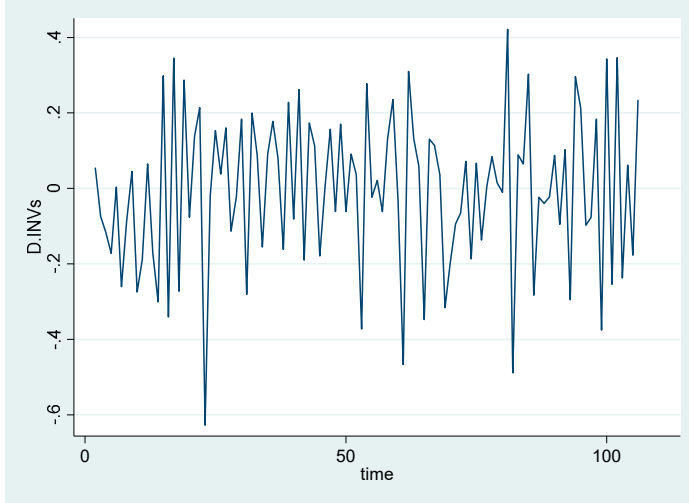

(b)

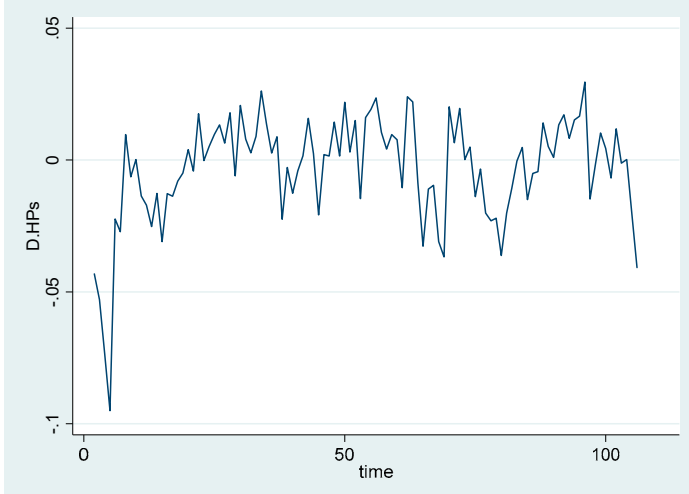

(d)

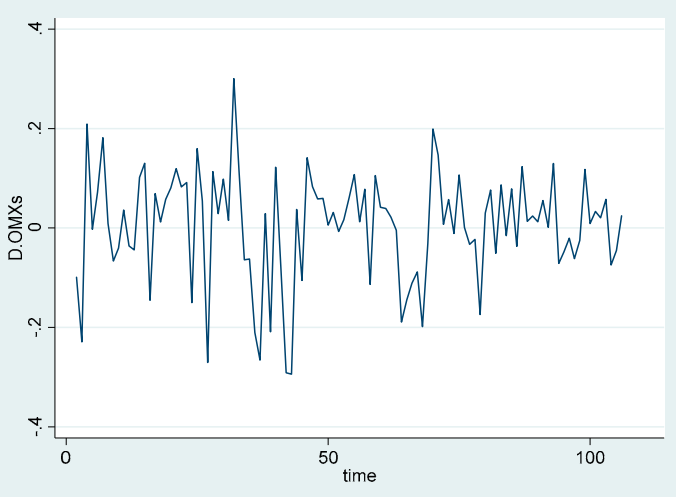

(g)

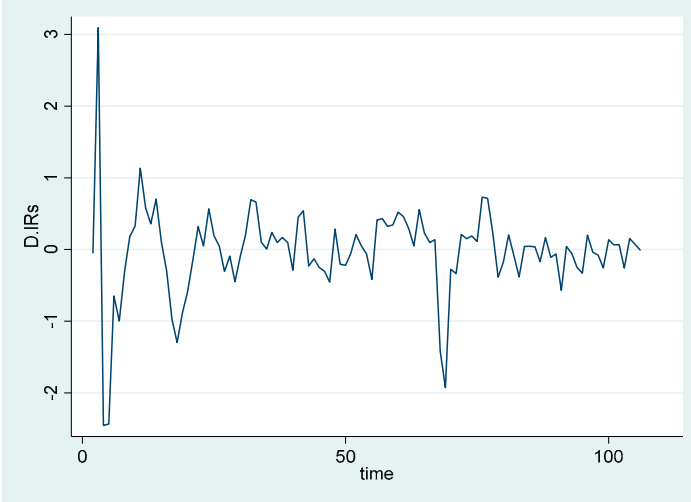

(i)

Figure 1. Quarterly first-difference data, seasonal and trend adjusted GDP, INV, CON, HP, BL, OMX, $F X$, and IR. 
All eight variables (a-i) illustrated in Figure 1 refer to the first-difference of seasonally and trend-adjusted series. All series are stationary, which we require to be able to interpret the impulse response effects estimated with the structured VAR model. Many of the series are trend stationary, but here we have chosen to use only the first-difference. Most of the series exhibit relatively high volatility, and particularly, the volatility is clustered over time. Some of the series also shows sharp spikes. This applies, for example, to bank loans, exchange rates, and interest rates.

Step two of the analysis has been to test the optimal lag structure in the VAR analysis. It has been done with the final prediction error (FPE), Akaike's information criterion (AIC), Schwarz's Bayesian information criterion (SBIC), and the Hannan and Quinn information criterion (HQIC) lag-order selection statistics. The results of these test sizes are not entirely conclusive. FPE and AIC show that 2 is the optimal lag, while SBIC and HQIC show that 0 is the optimal lag in tests where 4 is the maximum lag. If instead, the maximum lag is 8 , the AIC test will show that the optimal number of lag is 8 , while the other tests show the same result. Based on the test statistics, we have chosen to estimate the VAR model with a lag of 1,2,4, and 8. In the next step, we have estimated a simple VAR model and tested for eigenvalue stability and a Lagrange multiplier (LM) test for autocorrelation in the residuals of VAR models. Then, we have estimated the Granger causality. All the eigenvalues lie inside the unit circle. Hence, VAR satisfies stability conditions. Based on the Lagrange multiplier test, we cannot reject the null hypothesis of no autocorrelation at lag order 1-8.

\subsection{Granger Causality}

Granger causality shows some surprising results, but in essence, the result is in line with both theory and previous empirical findings. The results from the Granger causality analysis are shown in Figure 2.

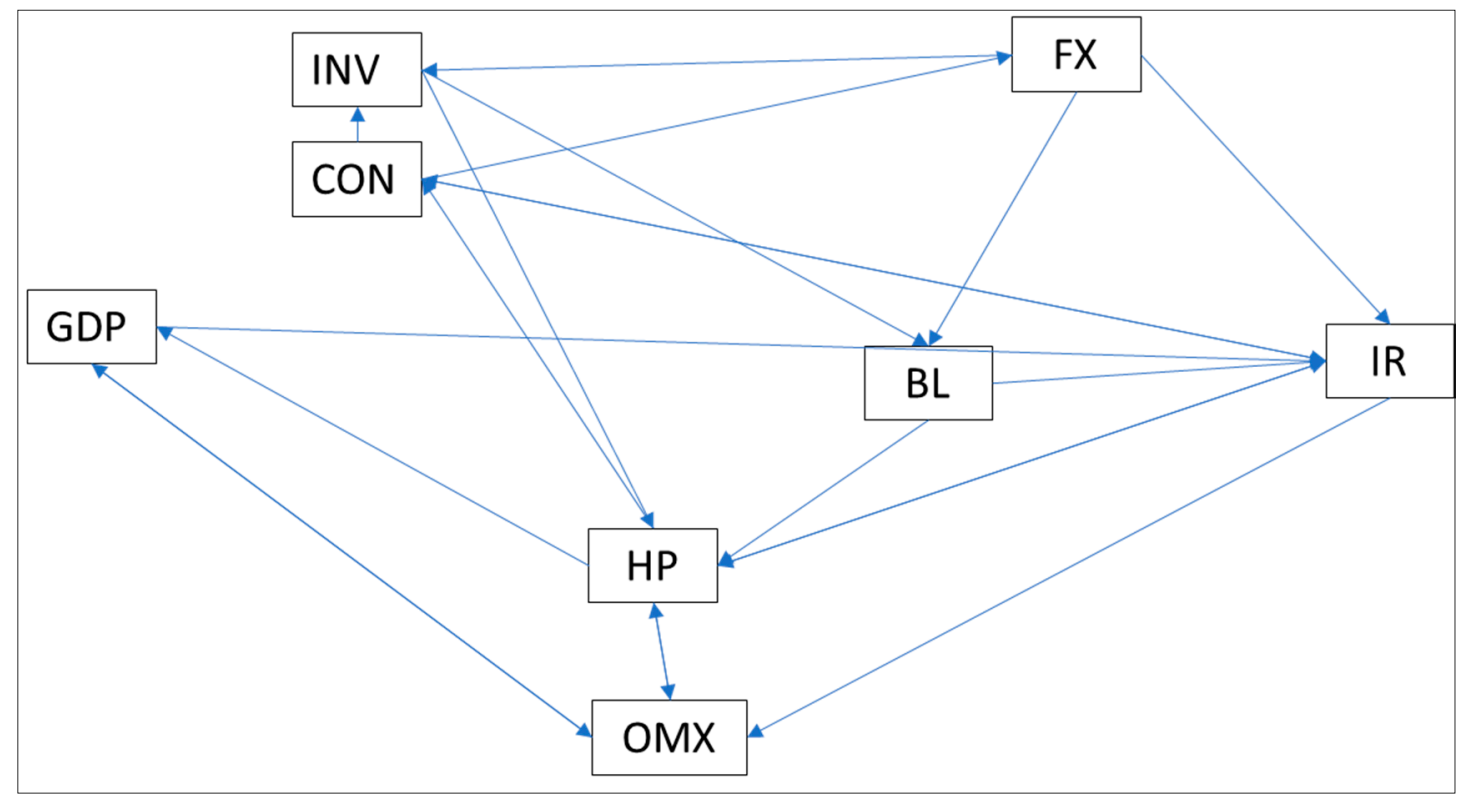

Figure 2. Granger causality.

When it comes to GDP, there is a Granger causality from all variables jointly on GDP. However, only house prices and stock market index have a statistically significant Granger impact on GDP. The exchange rate is the variable that statistically has the least impact on GDP. Consumption and exchange rate have a Granger causality residential investment. When it comes to consumption, it is house prices and interest rates that is Granger caused. House prices are Granger caused by almost all variables. Only GDP, consumption, and exchange rate are not statistically significant. The stock market index is Granger caused by GDP, house prices, and interest rate. Surprisingly, bank lending is 
only affected by residential investments and exchange rates, while the exchange rate is only affected by consumptions. Finally, the interest rate is Granger caused by almost all variables except residential investments and stock market index. Hence, bank lending and house prices are not bi-directional over the entire analyzed period that has been shown in earlier literature, for example, Goodhart and Hofman (2008), as well as Oikarinen (2009) in Finland and Öhman and Yasdanfar (2017) in Sweden.

\subsection{Structured Vector Autoregressive Model}

In the next step of the analysis, we are estimating that the SVAR model presents the results with the impulse response function and the variance decomposition. As said earlier, the short-run SVAR models identify the response by placing restrictions on the contemporaneous correlations between the included variables. The results from the SVAR model are shown below in the cumulative orthogonalized impulse response functions in Figures 3-5. Each figure gives the impulse responses over eight quarters to a one-standard-deviation positive shock in interest rate, bank lending, and stock market index, respectively. The grey band around the impulse response function is the $95 \%$ confidence interval.

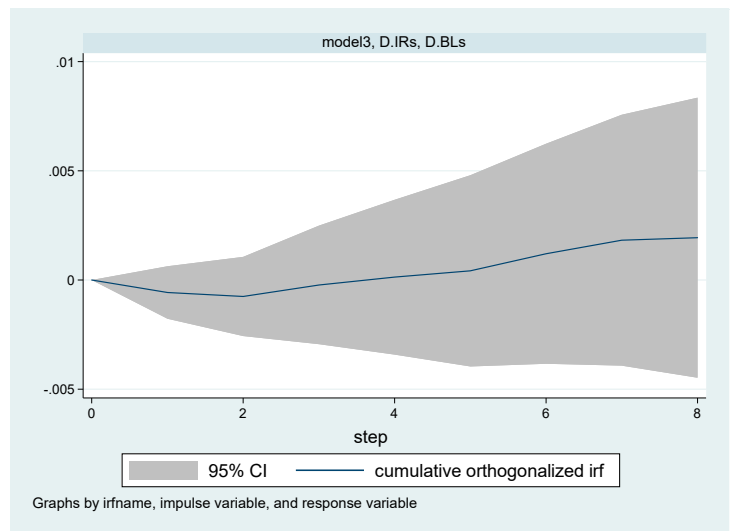

(a)

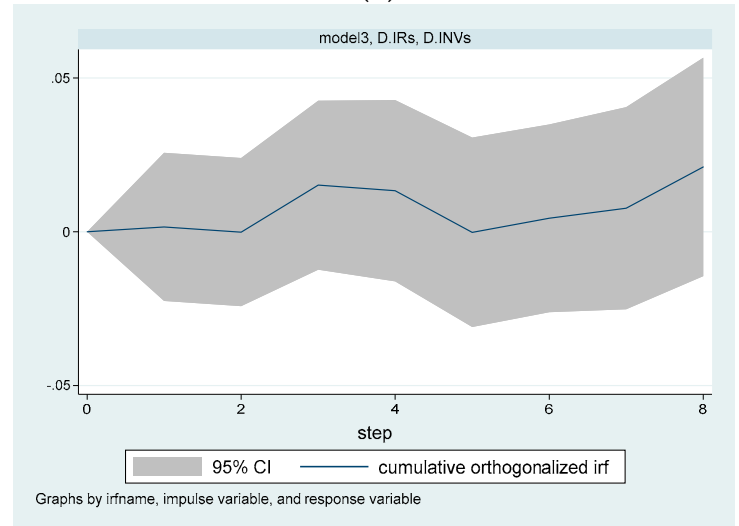

(c)

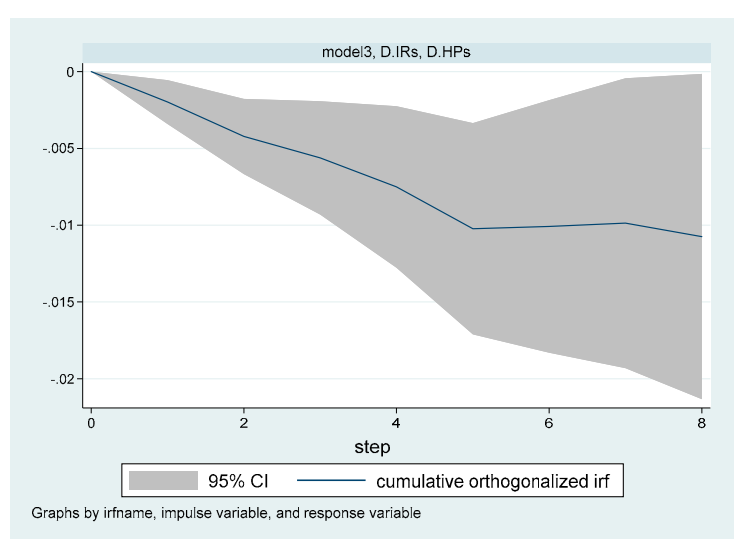

(b)

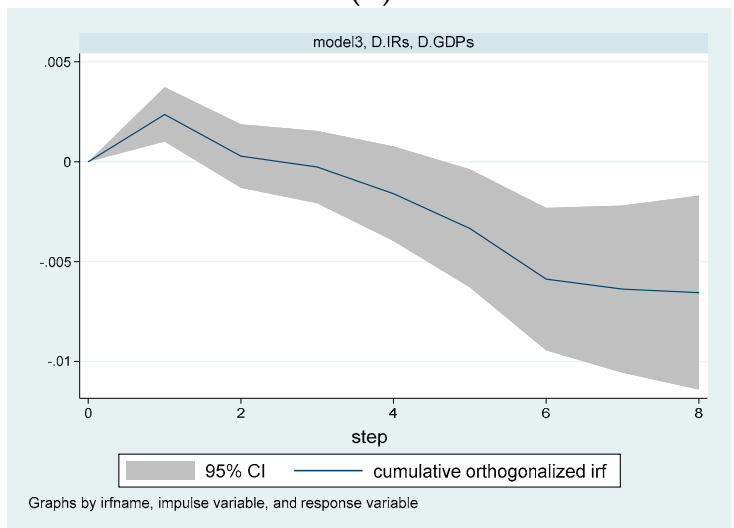

(d)

Figure 3. Interest rate channel. Impulse responses of aggregates to interest rate shock. 


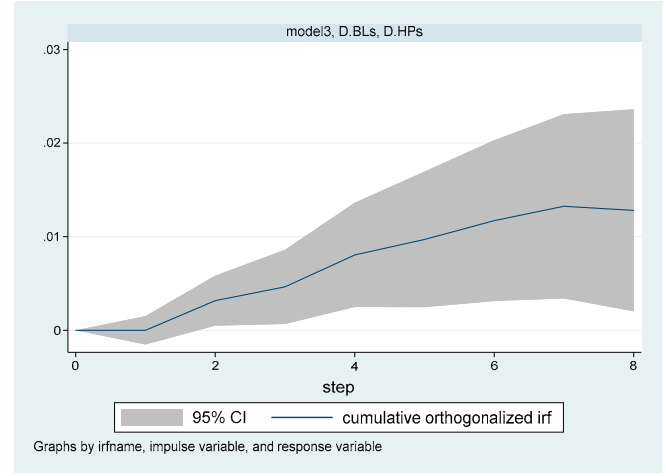

(a)

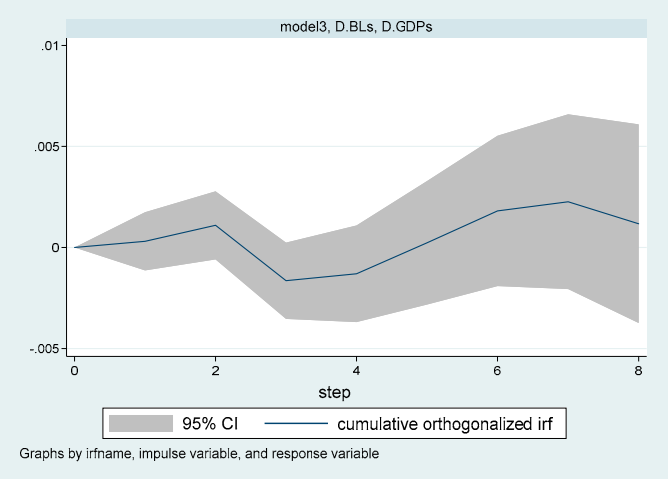

(c)

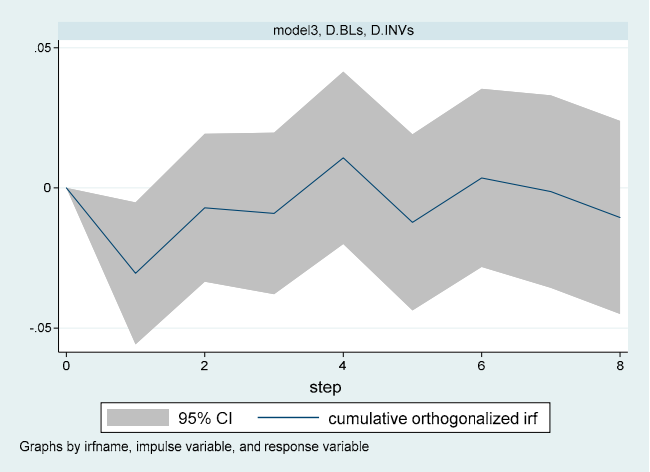

(b)

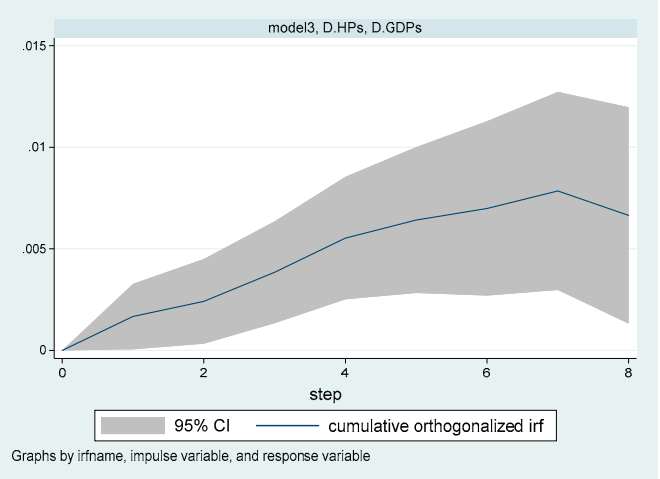

(d)

Figure 4. Bank lending channel. Impulse responses of aggregates to bank lending and house price shock.

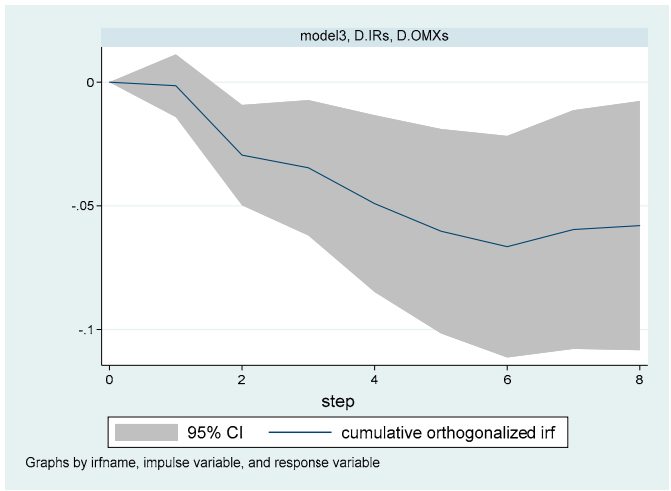

(a)

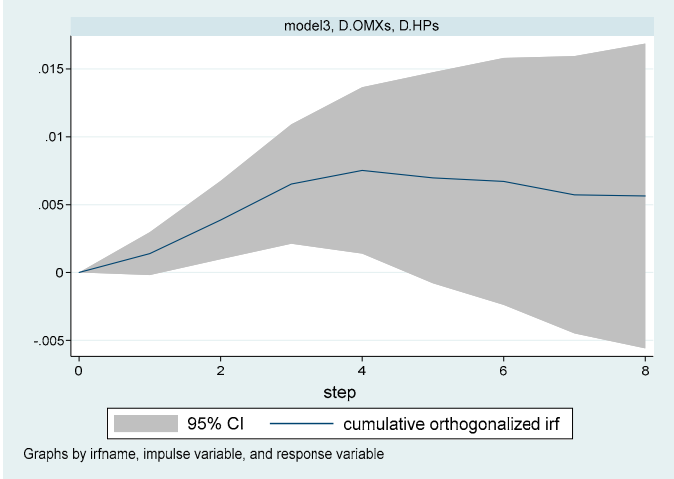

(c)

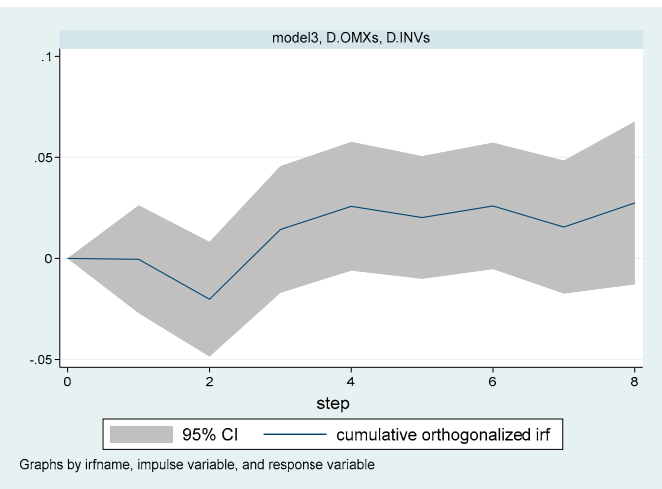

(b)

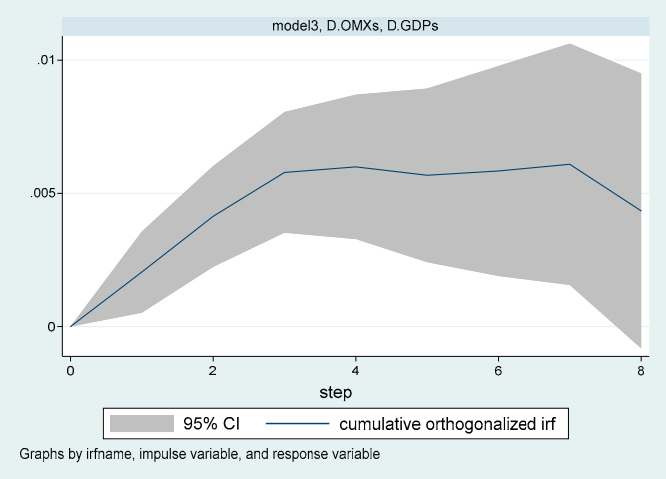

(d)

Figure 5. Liquidity effect channel. Impulse responses of aggregates to shocks. 


\subsubsection{Interest Rate Channel}

Figure 3 shows the estimated aggregated impulse responses to an interest rate shock; that is, it illustrates the interest rate channel.

The response to bank lending is decisive, small, and not significantly different from zero (Figure 3a). In response to an interest rate shock, initially, the house prices are significantly lower in quarter one (Figure 3b), and the impact is persistence the next coming four quarters. The large response of house prices may be a result of high LTV and adjustable mortgage interest rates. The same effect for Sweden can also be seen in, for example, Giuliodori (2005), Elbourne (2008), and Rahal (2016). The same is true for residential investments (Figure 3c).

On the other hand, the impulse response on GDP is significantly negative and persistent (Figure 3d) over the medium run (three to four quarters). To summarize, we can note that the traditional interest rate channel is of great importance. An interest rate shock will affect aggregate demand, and the housing market is vital as a transmission mechanism.

\subsubsection{Bank Lending Channel}

Figure 4 shows the estimated aggregated impulse responses to a bank lending shock and house price shock; that is, it illustrates the bank lending channel.

As shown in the figure, the house prices, HP, rises 2-6 quarters due to a shock in bank lending (Figure 4a). The increase in house prices could reflect that more capital is available for households and used to bid up house prices. These results are in accordance with Iacoviello and Minetti (2008), concerning Finland and the UK. The impulse response to housing investments is not significantly different from zero (Figure 4b). Some of the reasons for this may be that the construction of housing is relatively little dependent on bank lending, that we have previously had a system of construction subsidies, and that a relatively large proportion of the construction consists of rental apartments where we do not have market rents, as well as the fact that the effect is more delayed than only two years. Moreover, the response to the GDP is positive via the housing market (Figure 4c,d). To sum up, we can note that the bank lending channel is also an essential mechanism from changing short-term interest rates to bank lending, higher asset prices, and increased aggregate demand.

\subsubsection{Household Liquidity Effect Channel}

Figure 5 shows the estimated aggregated impulse responses to a wealth shock; that is, the liquidity channel in the transmission mechanism.

The initial impact of an interest rate shock on the stock market index is significantly negative (Figure 5a). A positive shock in the stock market, in turn, has both a positive impact on residential investments (Figure 5b) and house prices (Figure 5c). Moreover, the impact response on GDP from a shock on the stock market is also positive (Figure $5 \mathrm{~d}$ ). The full effect is capitalized on the market within a year. To summarize, it can be noted that the household's liquidity channel is relatively important as a transmission mechanism. Changes in interest rates are expected to increase both the values in real as financial assets, and these, in turn, have a positive effect on aggregate demand. These results are in contrast to the results by, Yang et al. (2017) One explanation for this can be that the housing market in Sweden can be characterized by high housing prices and high household debts, which indicate that the financial economy is as vital as the real economy for the housing market.

\subsection{The Variance Decomposition to Shocks}

In Figures 6 and 7, we are decomposing the variance for the variables house prices and housing investments, that is, the figures show the share of the total variation of the housing investment and housing prices associated with each specific shock. The results in Figure 6 seem to indicate that housing price volatility is driven by shocks in housing prices, around $50 \%$ after eight quarters. Shocks also drive the housing price volatility in bank lending and interest rate. 


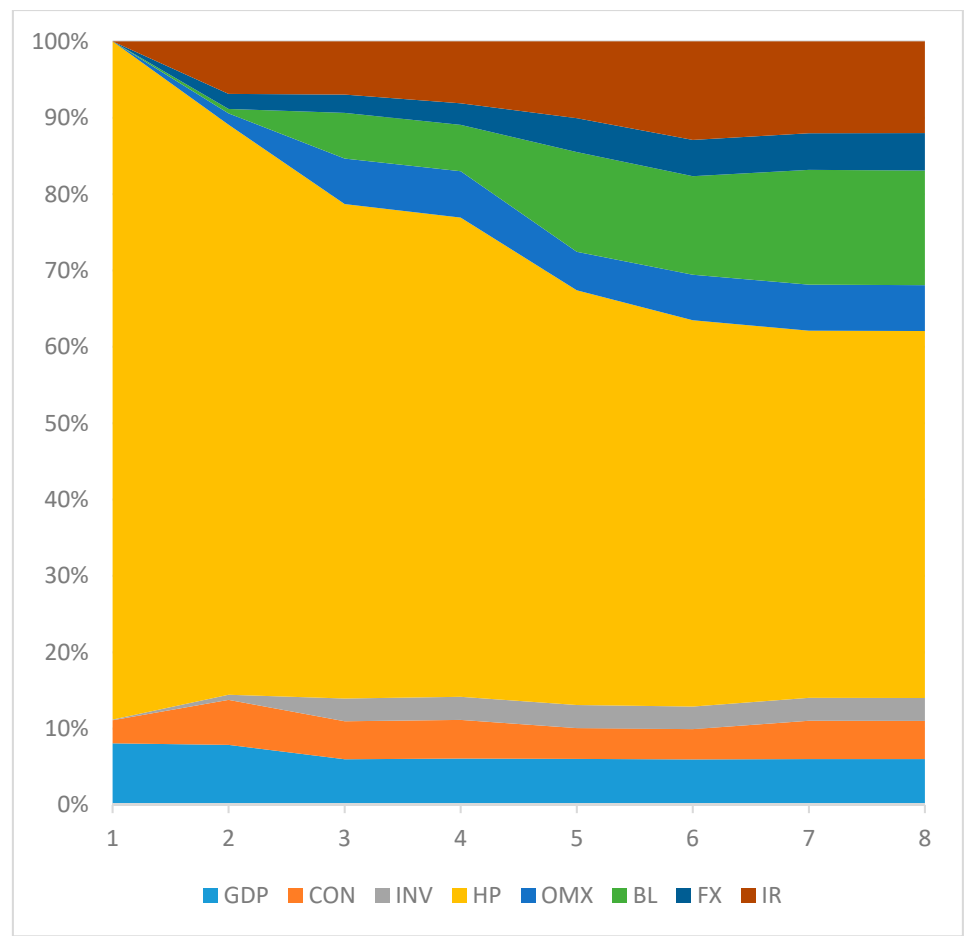

Figure 6. The variance decomposition to housing price shock.

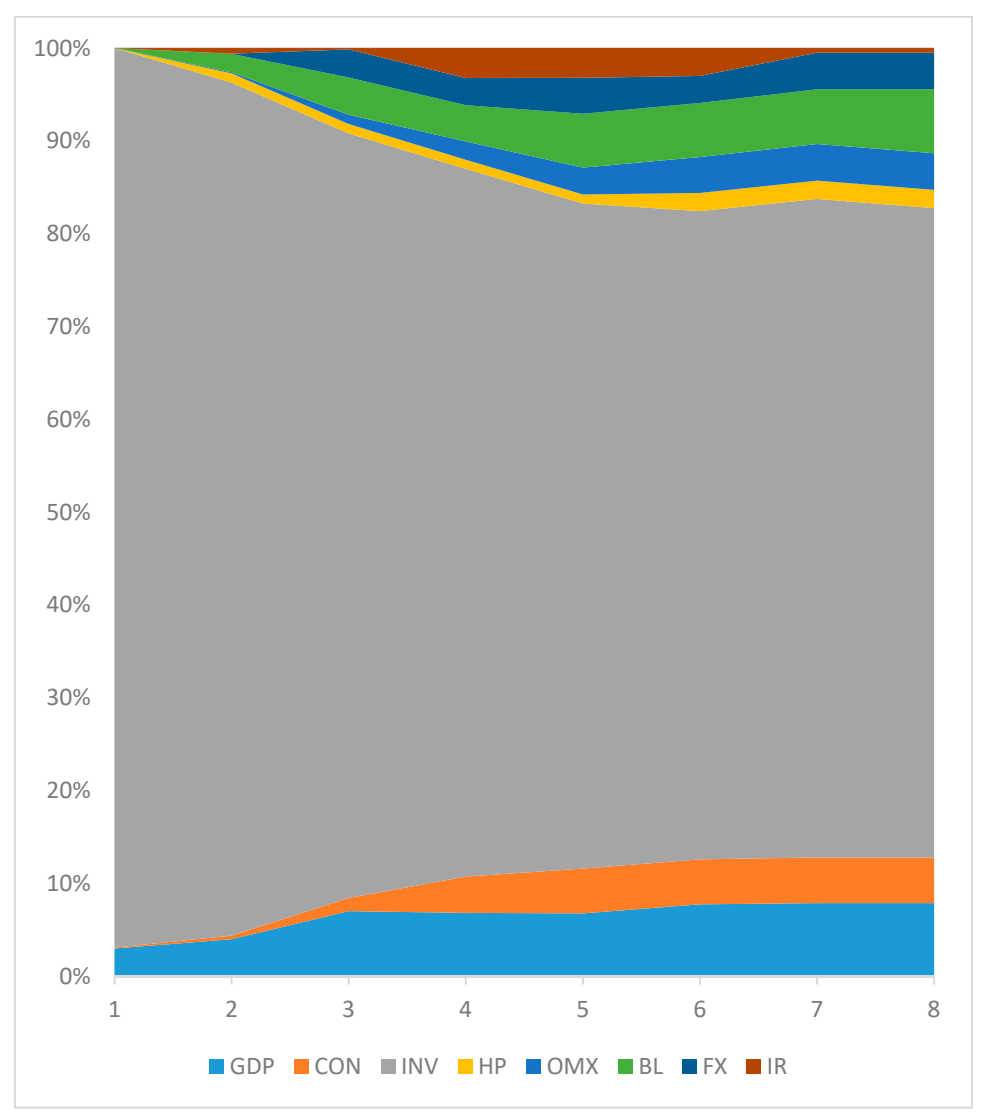

Figure 7. The variance decomposition to residential investment shock.

The estimates in Figure 7 suggest that the volatility in housing investment is mainly driven by shocks in housing investments, around $70 \%$ after eight quarters. These results are in accordance with, for example, Giuliodori (2005). 


\subsection{Parameter Heterogeneity}

As Canova and Forero (2015) concludes, assuming constant coefficients SVAR models may give misleading evidence when the structure of the market or the institutional context is shifting over time. Feldkircher and Huber (2018) also find in their analysis that the effect varies over time in the same country. For example, the effectiveness in monetary policy had a smaller effect on aggregated demand in the period before the great financial crises than after. Empirically, both Iacoviello and Minetti (2008), Björnlund and Jacobsen (2010), and, more recently, Fisher et al. (2019) have shown that the transmission mechanism varies depending on an institutional context. The institutional context does not only vary between countries, but it also varies over time. We have, therefore, estimated the SVAR model over the period before and after the financial crises in 2008. Hence, we are using the non-overlapping period approach. In Figure 8, below four impulse response functions are displayed. They all represent impacts via the interest rate channel, bank lending channel, and liquidity channel after the great financial crises.

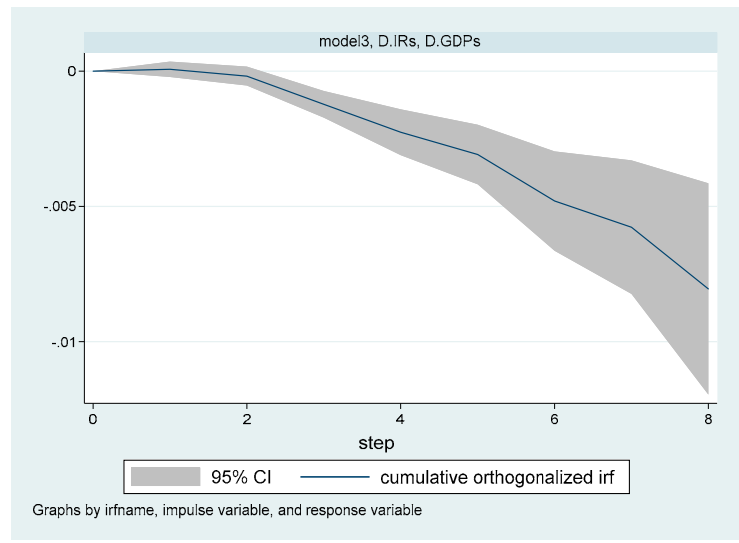

(a)

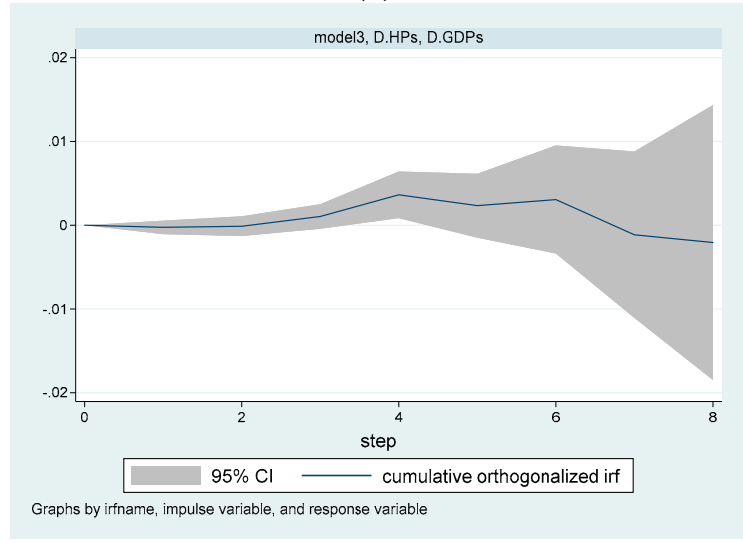

(c)

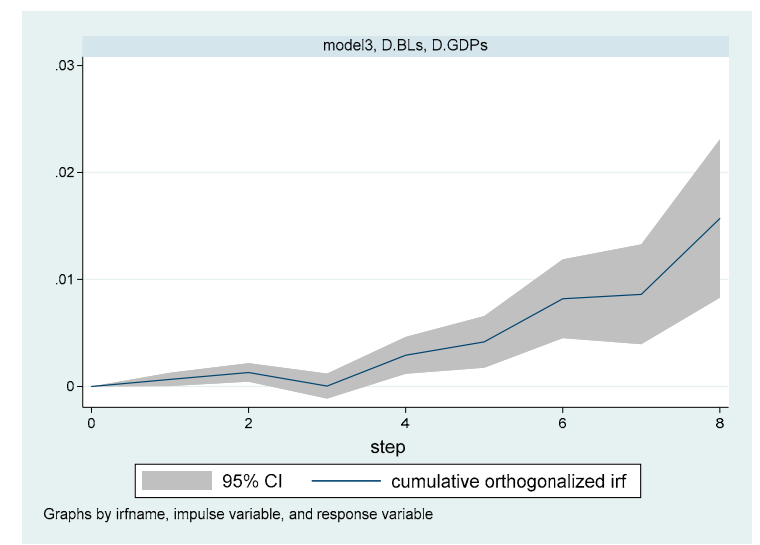

(b)

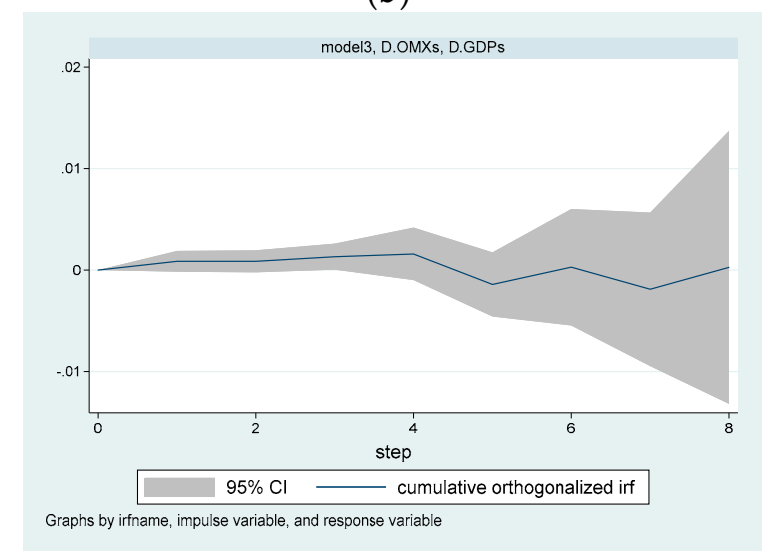

(d)

Figure 8. Impulse Responses of aggregates to shock in different aggregates.

What we can observe is that the interest rate channel is stable over time in terms of the effect on the GDP (Figure 8a). In the case of the bank lending channel, the results show that over the entire period, the effect reaches its peak after about seven quarters, while with the effect after the financial crisis, the effect increases during all eight quarters (Figure $8 \mathrm{~b}$ ). The magnitude of the effect also appears to be higher, which indicates that the bank lending channel is more prominent after the crisis than pre-crisis. The importance of the liquidity channel has diminished over time. The effect of changes in housing prices and the stock market have both been more substantial over the entire period examined compared to the period following the financial crisis (Figure $8 c, d$ ). In summary, we can see that the traditional interest rate channel has been equally strong both before and after the financial crisis. The 
bank lending channel has become stronger after, and the liquidity channel has become weaker after the financial crisis.

\section{Conclusions and Policy Implications}

From a theoretical point of view, we can assume that an expansive monetary policy will decrease mortgage rates, and via increased bank lending, house prices will rise in the short-run, and in the long-run, housing investments will increase. That will be the case if the transmission mechanism and the bank-lending channel is working. However, there have been several articles that show that the relationship between bank lending and house prices is not bi-directional. Hence, the demand for credits is a function of house prices, but not vice versa. The primary purpose of the present study was to investigate the relationship between bank lending and house prices, as well as analyzing the different transmission mechanism channels involving housing prices and residential investments.

To analyze the research question, we have designed and estimated a structured vector autoregressive model that includes eight different variables. These comprise the gross domestic product, household consumption, housing investments and housing prices, the stock market index, and the exchange rate, as well as bank lending and short-term interest rates. Restrictions on the short-term relationships between the variables have made it possible to identify estimated relationships. The main results are presented by impulse response function and variance decomposition analysis.

The main finding can be summarized as:

(1) The Granger causality analysis shows that there is a direct effect between the interest rate level and housing prices. The effect is bi-directional. There is no immediate effect between interest rate level and housing investment. Moreover, through the bank lending channel, we can observe an indirect impact, to such an extent that the interest rate affects bank lending, which in turn has affected housing prices.

(2) The Impulse response analysis shows some interesting results. For example, we can observe that a shock in interest rates will have an apparent significant effect on bank lending and housing prices, but not on housing investment over the eight quarters we investigate. A shock in bank lending will have a definite impact on housing prices, but no impact on housing investment. On the other hand, a shock in house prices will affect both bank lending and housing investment. Hence, it seems that the bank lending channel is at least as prominent as the traditional interest rate channel.

(3) The variance decomposition analysis shows that much more of the housing prices can be explained by the fundamental variables such as GDP, interest rates, and consumption, while the fundamentals can explain a smaller proportion for housing investment.

(4) The results also indicate that the increased percentage of households with an adjustable mortgage rate and other institutional changes over time has meant that the bank lending channel has become more important after 2007 compared to before. Today, the results indicate that the traditional interest rate channel is more important than the liquidity channel.

Hence, the results show that the transmission mechanism changes over time. In specific periods, the traditional interest rate channel is more efficient, while in others, the bank lending channel is more efficient. The results also show that the degree of efficiency changes over time as institutional conditions change. Monetary policy thus has different effects in different periods, and that is something policymakers and the central bank should take into account in their macroeconomic forecasting models. The results further show that decision-makers at different levels should take into account that the housing market is affected to varying degrees. The increased interest rate sensitivity in recent years (higher LTV quotas and more variable mortgage rates) has made the housing market more affected by the financial economy today than some decades ago. Finally, we can note that monetary policy affects housing investment to a very small extent. This market is more affected by fiscal policy in the form of taxes and subsidies, as well as land-use policies and building restrictions. However, monetary policy has a definite effect on housing prices. The analysis has increased the knowledge of the role that the 
housing market plays for the transmission mechanism, which is necessary for both the implementation of macroprudential tools and monetary policies.

Funding: The project was funded by Housing 2.0 (Bostad 2.0).

Acknowledgments: We thank the Mäklarstatistik AB for transaction data.

Conflicts of Interest: The authors declare no conflict of interest.

\section{References}

Abel, Andrew B., Ben Shalom Bernanke, and dean Croushore. 2014. Macroeconomics, 8th ed. New York: Pearson, p. 978, ISBN-13: 978-0-273-79230-7.

Anundsen, André K., and Eilev S. Jansen. 2013. Self-reinforcing effects between housing prices and credit. Journal of Housing Economics 2: 192-212.

Bernanke, Ben Shalom, and Alan S. Blinder. 1988. Credit, money and aggregate demand. American Economic Review 78: 435-39.

Bernanke, Ben Shalome, and Mark Gertler. 1989. Agency costs, net worth, and business fluctuation. American Economic Review 79: 14-31.

Björnlund, Hilde C., and Dag Henning Jacobsen. 2010. The role of house prices in the monetary policy transmission mechanism in small open economies. Journal of Financial Stability 6: 218-29. [CrossRef]

Calza, Alessandro, Tommaso Monacelli, and Livio Stracca. 2013. Housing finance and monetary policy. Journal of the European Economic Association 11: 101-22.

Canova, Fabio, and Fernando J. Pérez Forero. 2015. Estimating overidentified, nonrecursive, time-varying coefficients structural vector autoregressions. Quantitative Economics 6: 359-84.

Chari, Varadarajan, Patrick Kehoe, and Ellen McGrattan. 2008. Are structural VARs with long-run restrictions useful in developing business cycle theory? Journal of Monetary Economics 55: 1337-52. [CrossRef]

Christidou, Maria, Panagiotis Th. Konstantidou, and Costas Roumanias. 2018. Heterogeneous monetary policy transmission in the housing market. Review of Economic Analysis 10: 75-96.

Elbourne, Adam. 2008. The UK housing market and the monetary policy transmission mechanism: An SVAR approach. Journal of Housing Economics 17: 65-87. [CrossRef]

Feldkircher, Martin, and Florian Huber. 2018. Unconventional US Monetary Policy: New Tools, Same Channels? Journal of Risk and Financial Management 11: 71. [CrossRef]

Fisher, Manfred M., Florian Huber, Michael Pfarrhofer, and Petra Staufer-Steinnocher. 2019. The dynamic impact of monetary policy on regional housing prices in the United States. Real Estate Economics, 1-30.

Forni, Mario, and Luca Gambetti. 2014. Sufficient information in structural VARs. Journal of Monetary Economics 66: 124-36. [CrossRef]

Gerlach, Stefan, and Wensheng Peng. 2005. Bank lending and property prices in Hong Kong. Journal of Banking and Finance 29: 461-81. [CrossRef]

Giuliodori, Massimo. 2005. Monetary Policy Shocks and the Role of House Prices Across European Countries. Scotland Journal of Political Economy 54: 519-43.

Goodhart, Charles, and Boris Hofman. 2008. House prices, money, credit, and the macroeconomy. Oxford Review of Economic Policy 24: 180-205. [CrossRef]

Iacoviello, Matteo, and Raoul Minetti. 2008. The credit channel of monetary policy: Evidence from the housing market. Journal of Macroeconomics 30: 69-96. [CrossRef]

Mishkin, Frederic S. 2007. The Economics of Money, Banking, and Financial Markets. Boston: Pearson, Addison-Wesley.

Oikarinen, Elias. 2009. Interaction between housing prices and household borrowing: The Finnish case. Journal of Banking and Finance 33: 747-56. [CrossRef]

Öhman, Peter, and Darush Yasdanfar. 2017. Bank lending and housing prices in Sweden. International Journal of Housing Markets and Analysis 11: 498-519. [CrossRef]

Rahal, Charles. 2016. Housing markets and unconventional monetary policy. Journal of Housing Economics 32: 67-80. [CrossRef]

Sims, Christopher A. 1980. Macroeconomics and reality. Econometrica 48: 1-48.

Wadud, Mokhtarul I. K. M., Omar H. M. N. Bashar, and Huson Joher Ali Ahmed. 2012. Monetary policy and the housing market in Australia. Journal of Policy Modeling 34: 849-63. [CrossRef] 
Wu, Lili, and Yang Bian. 2018. Housing, consumption and monetary policy: how different are the first-, secondand third-tier cities in China? Applied Economic Letters 25: 1107-11.

Yang, Zan, Shuping Wu, and Yanhao Shen. 2017. Monetary policy, house prices, and consumption in China: A national and regional study. International Real Estate Review 20: 23-49.

(C) 2020 by the author. Licensee MDPI, Basel, Switzerland. This article is an open access article distributed under the terms and conditions of the Creative Commons Attribution (CC BY) license (http://creativecommons.org/licenses/by/4.0/). 